Originalni naučni rad

Primljeno: 29. 10. 2016.

Revidirana verzija: 26. 12. 2016.

UDK: 572.512:351.74-051(536.2)

Prihvaćeno: 24. 1. 2017.

doi: $10.5937 /$ nabepo21-12244

\title{
STRUCTURAL ANALYSIS OF BODY COMPOSITION STATUS IN ABU DHABI POLICE PERSONNEL
}

Filip Kukić ${ }^{1}$

\author{
Milivoj Dopsaj ${ }^{2}$ \\ University of Belgrade \\ Faculty of Sport and Physical Education
}

Summary: Monitoring of morphological status is necessary because human body structure is very important and at the same time biologically very changeable category that can be influenced by many external and internal factors. The aim of this study is a structural analysis of current state of body composition for purposes of establishing initial body composition model of Abu Dhabi police personnel. Measurement procedures have been conducted under the monitoring of Strategic Management \& Performance Improvement Department, Sports Activity Section, Abu Dhabi police, in the gym for police officers with the help of the machine InBody 720 . The sample size was 59 male police officers of different age and rank. The main characteristics of the sample were: age $31.53 \pm 9.42$ years, height $173.08 \pm 6.13 \mathrm{~cm}$ and body weight $80.10 \pm 11.50 \mathrm{~kg}$. Investigated variables were: height $(\mathrm{H})$, body weight (BW), body mass index (BMI), body fat mass (BFM), percent of body fat (PBF), skeletal muscle mass (SMM) and per-

$1 \mathrm{PhD}$ student, the Strategic Management \& Performance Improvement Department, Sport Activity Section, United Arab Emirates.

2 Full Professor. 
cent of skeletal muscle mass (PSMM). Statistically, the results were calculated by descriptive statistics and cluster analysis. The results have shown that prevalence of the overweighed according to the $\mathrm{WHO}$ was $59.06 \%$, prevalence of obesity according to ACE was $49.15 \%$ and $66.10 \%$ of the sample had under average PSMM.

Keywords: BMI, PBF, SMM, body composition, bioelectrical impedance.

\section{Introduction}

Police officers have a wide range of responsibilities which include long hours in seated position at the office desk, traffic and walking patrols, securing individuals and facilities, public manifestations and gatherings, and many others. Implementing rules and laws among people requires an enormous amount of analytical thinking and emotional control. These are important to take into account while they directly affect the levels of stress that each in the task force is exposed to. In addition to the above mentioned, we have to take into account the physical effort that those men are experiencing. Their physical effort can vary from situation to situation, from bare minimum to a close to, if not, absolute maximum. ${ }^{3,4}$ Therefore, the selection process for this profession and the department control of health and physical status of policemen are very important processes during their career. Regarding that, the first, very visible indicators of health and physical status can be detected by regular follow up on body composition. ${ }^{5}$

It is widely known that body composition is the result of various factors such as diet, stress, the amount of physical activity and other factors that are parts of daily habits. Thus we take body composition as a reliable indicator of the current health. Research has shown that skeletal muscle mass in men decreases with age ${ }^{6}$ which is led by the decrease of strength at about $5 \%^{7}$ overall.

3 Sorensen, J. S; Physical activity, fitness and body composition of Finnish police officers: a 15-year follow-up study. Occupational Medicine, issue 50, volume 1/2000, pages 2-10. 4 Dimitrijević, R., Umičević D., Dopsaj, M; Mofološki model ženskih pripadnika komunalne policije Beograda, Glasnik antrolološkog društva Srbije, 48/2013, pages 97-106.

5 Despres, J., Lamarche, B; Effects of diet and physical activity on adiposity and body fat distribution: implications for the prevention of cardiovascular disease, Nutrition Research Reviews, Vol. 6/1993, pages 137-159.

6 Hughes, V; Longitudinal changes in body composition in older men and women: role of body weight change and physical activity, American Journal of Clinical Nutrition, issue 76, volume 2/2002, pages 473-81.

7 Goodpaster, B; The loss of skeletal muscle strenght, mass, and quality in older adults: The health, aging and body composition study. Journal of Gerontology, issue 61A, volume 10/2006, pages 1059-64. 
Contrary, increase in body fat mass over criterion levels brings up the risk of cardio-vascular diseases, high blood pressure, diabetes and according to some researches mortality as well. ${ }^{8,9}$ Body composition monitoring is necessary because human body structure is very important, and at the same time biologically very inconsistent category. This is due to numerous external influences coexisting together with internal factors. ${ }^{10}$

Skeletal muscle mass recently has been mostly measured. It has the role of great importance in quality and quantity of movement in humans, which is in accordance with general health standards and along with it general requirements for police officers. ${ }^{11,12,13}$ Its biological role is essential because of many other positive influences on body health status. These include better basal metabolic rate, higher quality body posture, improved blood flow, increased movement potential, etc. Furthermore, the amount of skeletal muscle mass is gender dependent and it decreases with age. This brings negative effects on health and overall quality of life. ${ }^{14,15,16}$ Accordingly, skeletal muscle mass has very important place in this study because according to our knowledge there are no publications on the population of Abu Dhabi police that dealt with the structural analysis of this factor of body composition.

Body height represents a longitudinal measure of the body, while body weight is a measure of body volume. The most basic way to evaluate body composition is regarding valid biological standards where body weight has consisted of fat-free mass - skeletal muscle mass and body fat mass. Another

8 Stevens, J. C; The effect of age on the association between body-mass index and mortality. The New England Journal of Medicine, issue 338, volume 1/1998, pages 1-7.

9 Andern, C., Katzmarzyk, P., Janssen, J., Ross, R; Discrimination of health risk by combined Body Mass Index and waist circumference, Obesity Research, issue 11, volume $1 / 2003$, pages $135-142$.

10 American Council on Exercise, Retrieved from: https://www.acefitness.org/acefit/ healthy-living-article/60/112/what-are-the-guidelines-for-percentage-of-body-fat

11 Spitler, D.L., Facsm, J., Hawkins, J., Dudka, L; Body composition and physiological characteristics of law enforcement officers. British Journal of Sports Medicine, issue 21, volume 4/1987, pages 154-157.

12 Janssen, I., Heymsfield, S. R., Ross, R; Low relative skeletal muscle mass is associated with functional impairment and physical disability, Journal of the American Geriatrics Society, issue 50, volume 5/2002, pages 889-896.

13 Rakić, S., Marković, M., Dopsaj, M., Mlađan D., Subošić, D; Initial model of Men's muscle structure indicators defined by the method of Multichannel Bioelectrical Impedance, Facta Universitatis, Series: Physical Education and Sport, issue 11, volume 1/2013, pages 23-33.

14 Janssen I., Heymsfield, B., Wang, Z., Ross, R; Skeletal muscle mass distribution in 468 man and women aged, Journal of Applied Physiology, issue 89, volume 1/2000 a, pages 81-88. 15 Janssen, I., Heymsfield, S., Baumgartner, R., Ross, R; Estimation of skeletal muscle mass by bioelectrical impedance analysis. Journal of Applied Physiology, issue 89, volume $2 / 2000^{b}$, pages $465-471$.

16 Janssen, I., Heymsfield, S. R., Ross, R, Opus citatum, pages 889-896. 
way for defining body composition (underweight, normal weight, overweight, obesity, etc.) is an index of body mass relative to body height - body mass index (BMI). This gives us an assumption whether the body is more fatty or more muscular. ${ }^{17}$ Numerous publications speak in favor of using BMI when it comes to an explanation of body composition and estimation of prevalence of obesity. 18, 19, 20 Also, it has been proven that percent of body fat (PBF) has a special place in explaining obesity level. This is due to the reason that BMI is highly influenced by PBF. Practically PBF allows more precise analysis of BMI and body morphology, especially in older people. ${ }^{21}$ Next to the fat mass, skeletal muscle mass is the second component of BMI of interest and methodologically it is very important to determine if $\mathrm{BMI}$ is the result of increased $\mathrm{PBF}$ or percent of skeletal muscle mass. Increment of PBF decreases potential of motor abilities, while increment of percent of muscle mass increases that potential which is highly important for better quality of life, higher professional competency, lowering stress level and better health. $22,23,24,25$

Police personnel are in charge of keeping the community safe and secure. Thus the process of selection for this job is a highly qualitative system of control and monitoring physical health of selected candidates. The nature of police work is often stressful, full of professional, physical and social pressures that gradually in time lead to accumulation of negative impacts on physiology and health. ${ }^{26,27}$ In that regard, by monitoring the morphological status level of general fitness could be indirectly estimated. This probably might be an indication of the level of professional working efficiency. Monitoring allows us to estimate morphological status as a measure of the external esthetic look of the police officer, but also it controls the possibility of the appearance of potential health risks as a preventive measure of safety against job-related risks, as well

17 Andern, C., Katzmarzyk, P., Janssen, J., Ross, R, Opus citatum, pages135-142.

18 Dopsaj M., Nešić, G., Korpanovski, N., Sikimić, M; Antropološki profil studentkinja KPA i različito treniranih sportiskinja - multi centroidni model, Nauka, Bezbednost, Policija, volume 14, broj 1/2009, str. 145-160.

19 Andern, C., Katzmarzyk, P., Janssen, J., Ross, R, Opus citatum, pages135-142.

20 Janssen, I., Heymsfield, S., Baumgartner, R., Ross, R, Opus citatum, pages 465-471.

21 Wannamethee, A., Shaper, G., Morris, R., Whincup, P; Measures of adiposity in the identification of metabolic abnormalities in elderly men, American Journal of Clinical Nutrition, issue 81, volume 5/2005, pages 1313-1321.

22 Janssen I., Heymsfield, B., Wang, Z., Ross, R; Skeletal muscle mass distribution in 468 man and women aged, Journal of Applied Physiology, issue 89, volume 1/2000a, pages 81-88. 23 Andern, C., Katzmarzyk, P., Janssen, J., Ross, R, Opus citatum, pages135-142.

24 Boyce RW, Jones GR, Lloyd CL, Boone EL; A longitudinal observation of police: body composition changes over 12 years with gender and race comparisons, Journal of Exercise Physiology, issue 11/2008, pages 1-13.

25 Dopsaj M., Nešić, G., Korpanovski, N., Sikimić, M, Opus citatum, str. 145-160.

26 Dimitrijević, R., Umičević D., Dopsaj, M, Opus citatum, pages 97-106.

27 Dopsaj, M., Vuković, M; Prevalenca indeksa telesne mase (BMI) kod pripadnika MUP-a Republike Srbije: Pilot istraživanje, Bezbednost, volume 3/2015, str. 28-48. 
as increased prevalence of obesity. To our knowledge, Abu Dhabi police do not have a system of evaluation of body composition status. However, it is obvious that there is scientific and professional need for conducting such research with the aim to make insight in the current state of body composition status and to establish the initial database for further development of the system of management and monitoring of Abu Dhabi police.

The aim of this study is a structural analysis of current body composition status for purposes of establishing an initial body composition model of Abu Dhabi police. This would contribute to the foundation for the development of an expert system of permanent monitoring of the general morphological status of Abu Dhabi police.

\section{Methods}

Research has been conducted as non-experimental according to the laboratory principles - using a random sample. It can be classified as applied scientific research.

\subsection{Participants}

Fifty-nine participants of different age and rank have been selected for this study. The main characteristics of the sample were: age $31.53 \pm 9.42$ years, height $(\mathrm{H}) 173.08 \pm 6.13 \mathrm{~cm}$ and body weight $(\mathrm{BW}) 80.10 \pm 11.50 \mathrm{~kg}$. All participants and trainers that conducted measurements were informed about the aim of the study, and the participants were measured only if they agreed to be a part of the study.

\subsection{Measurement procedure}

Measurement procedures have been conducted under the monitoring of the Strategic Management \& Performance Improvement Department, Sports Activity Section, Abu Dhabi police. We used the gym that belongs to police officers with the help of the InBody 720 machine. The participants were instructed to come in the morning before breakfast and fluid intake. However, they were coming anytime during the day when they were free and able to because of their working hours, which is 7:30 AM to 2:30 PM. To be as accurate as possible, they were instructed to fast at least 3 hours before measurement. All measurements were conducted using multi-channel bioelectric impedance 
InBody 720 (Biospace Co. Ltd, Seoul, Korea) following its standard procedures. All results were printed out and then typed in software Microsoft Excel.

The participants were measured in underwear, barefoot and all metal, plastic, and magnetic accessories were removed as proposed in previous research. ${ }^{28}$ To measure their weight first, they positioned feet on metal spots designed for feet. After that, the instruction was given to them to extend their posture and look straight as when their height is measured. After the machine had signaled the end of weight measurement, the participants took the handles with electrodes positioned on the lower and the upper edge of the handles. Four fingers were positioned on the bottom edge, and thumb was placed on the top edge. Hands were parallel to the body with $15-20^{\circ}$ of shoulder abduction. The participants were standing steady in this position until the sound and instructors signal that measurement procedure is over. All results were printed out and typed into Microsoft Excel database.

\subsection{Cluster criteria}

Using a huge sample of data the World Health Organization (WHO) made the classification of the prevalence of BMI on 7 clusters $^{29}$ is shown in Table 1.

Table 1. The International Classification of adult underweight, overweight, and obesity according to BMI

\begin{tabular}{|l|l|l|}
\hline General classification & \multicolumn{1}{|c|}{ Specific Classification } & \multicolumn{1}{c|}{$\mathbf{K g} / \mathbf{m}^{2}$} \\
\hline Underweight & Underweight & $<18.49$ \\
\hline \multirow{2}{*}{ Normal range } & Thin & $18.50-21.49$ \\
\cline { 2 - 3 } & Normal weight & $21.50-24.99$ \\
\hline Overweight & Muscular/Pre-obese & $25.00-27.49$ \\
\hline \multirow{3}{*}{ Obese } & Pre-obese & $27.50-29.99$ \\
\cline { 2 - 3 } & Obese class I & $30.00-34.99$ \\
\cline { 2 - 3 } & Obese class II and III & $>35.00$ \\
\hline
\end{tabular}

The American Council on Exercise (ACE) defined 5 clusters of the prevalence of $\mathrm{PBF}^{30}$ that are shown in Table 2. The sample of this study has been classified according to these clusters.

28 Ibidem, str. 28-48.

29 World Health Organisation. Retrieved from: http://apps.who.int/bmi/index.jsp?introPage=intro_3.html (25.09.2016)

30 American Council on Exercise, Retrieved from: https://www.acefitness.org/acefit/ healthy-living-article/60/112/what-are-the-guidelines-for-percentage-of-body-fat 
Table 2. The International Classification of PBF in adults according to ACE

\begin{tabular}{|l|l|l|}
\hline \multicolumn{1}{|c|}{ Classification } & \multicolumn{1}{c|}{ Female } & \multicolumn{1}{c|}{ Male } \\
\hline Essential Fat & $10.00-13.99 \%$ & $2.00-5.99 \%$ \\
\hline Skinny and Athletes & $14.00-20.99 \%$ & $6.00-13.99 \%$ \\
\hline Fitness & $21.00-24.99 \%$ & $14.00-17.99 \%$ \\
\hline Average & $25.00-31.99 \%$ & $18.00-24.99 \%$ \\
\hline Obese & $>32 \%$ & $>25 \%$ \\
\hline
\end{tabular}

Skeletal muscle mass was classified into 5 clusters according to Mean and Standard Deviation which was previously explained in Rakić et al. 2013.

Table 3. Cluster criteria for PSMM defined according to initial national standards ${ }^{31}$

\begin{tabular}{|l|l|}
\hline \multicolumn{1}{|c|}{ Classification } & \multicolumn{1}{c|}{ PSMM } \\
\hline Insufficient percentage of skeletal muscle mass & $<41.07$ \\
\hline Below average percentage of skeletal muscle mass & $41.08-45.41$ \\
\hline Average percentage of skeletal muscle mass & $45.42-49.75$ \\
\hline Above average percentage of skeletal muscle mass & $49.76-54.10$ \\
\hline Excellent percentage of skeletal muscle mass & $>54.11$ \\
\hline
\end{tabular}

\subsection{Statistic procedures}

A simple descriptive statistic was calculated including the measure of central tendency - Mean and measures of data dispersion - Standard Deviation (SD), Coefficient of variation (cV\%), Minimum (Min) and Maximum (Max). All variables were tested for normality of distribution using Skewness and Kurtosis as well as non-parametric Kolmogorov-Smirnov test. The prevalence of BMI, PBF, and PSMM was determined using cluster analysis. The prevalence of BMI was determined according to the $\mathrm{WHO}$ and the prevalence of PBF according to the ACE. PSMM was determined according to the procedures explained in previous publications. ${ }^{32,33}$ All of the statistical procedures were conducted in Microsoft Excel and statistical package SPSS Statistics 23.

31 Rakić, S., Marković, M., Dopsaj, M., Mlađan D., Subošić, D, Opus citatum, pages 23-33. 32 Ibidem, pages 23-33.

33 Dopsaj, M., Vuković, M, Opus citatum, str. 28-48. 


\section{Results}

Table 4 shows calculated descriptive statistics for the investigated variables.

Table 4. Descriptive statistics for investigated variables

\begin{tabular}{llllll}
\hline Variables & Mean & SD & cV\% & Min & Max \\
\hline AGE & 31.53 & 9.42 & 29.63 & 19.00 & 49.00 \\
\hline H $(\mathrm{cm})$ & 173.08 & 6.13 & 3.52 & 156.00 & 191.00 \\
\hline BW $(\mathrm{kg})$ & 80.10 & 11.50 & 15.40 & 53.00 & 109.60 \\
\hline BMI $\left(\mathrm{kg} / \mathrm{m}^{2}\right)$ & 26.76 & 3.74 & 14.95 & 17.11 & 34.78 \\
\hline BFM $(\mathrm{kg})$ & 34.47 & 4.78 & 24.70 & 13.88 & 46.30 \\
\hline PBF $\%)$ & 24.35 & 7.57 & 33.20 & 9.46 & 38.08 \\
\hline SMM $(\mathrm{kg})$ & 34.47 & 4.78 & 13.88 & 24.70 & 46.30 \\
\hline PSMM $(\%)$ & 43.31 & 4.49 & 10.37 & 34.79 & 51.69 \\
\hline
\end{tabular}

Normality of distribution for tested variables of the studied sample is shown on histograms 1-5. Based on these results it can be reliably said that there are no extreme individual results and that the distribution of data is normal for the variables of interest for this study - H, BW, PBF, BMI and PSMM. It has been additionally confirmed with Kolmogorov-Smirnov test for non-parametric statistics.
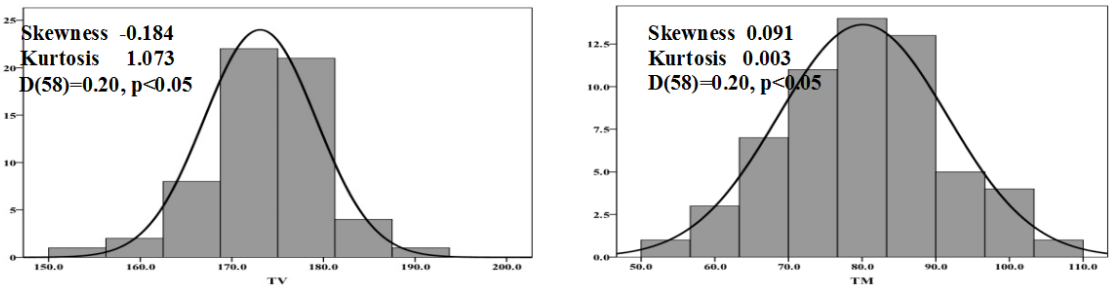

Graphs 1 and 2. Histograms of data distribution for $H$ and $B W$ for all participants, Skewness, Kurtosis and K-S test
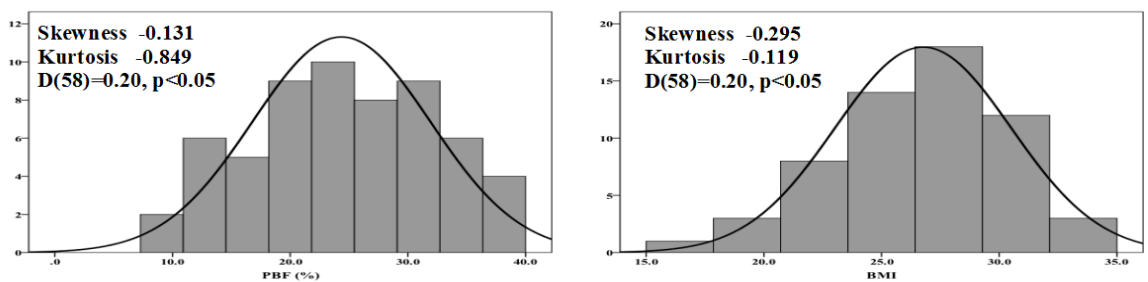

Graphs 3 and 4. Histograms of data distribution for PBF and BMI for all participants, Skewness, Kurtosis and K-S test

[26] NBP • Žurnal za kriminalistiku i pravo 


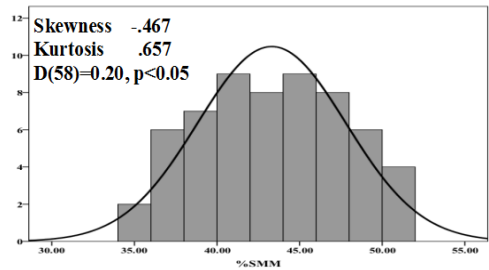

Graph 5. Histograms of data distribution for PSMM for all participants, Skewness, Kurtosis and K-S test

After the descriptive statistics and normality of distribution have been concluded, cluster analysis was applied for the primary variables for this study and those are BMI, PBF, PSMM (Graphs 6, 7, 8).

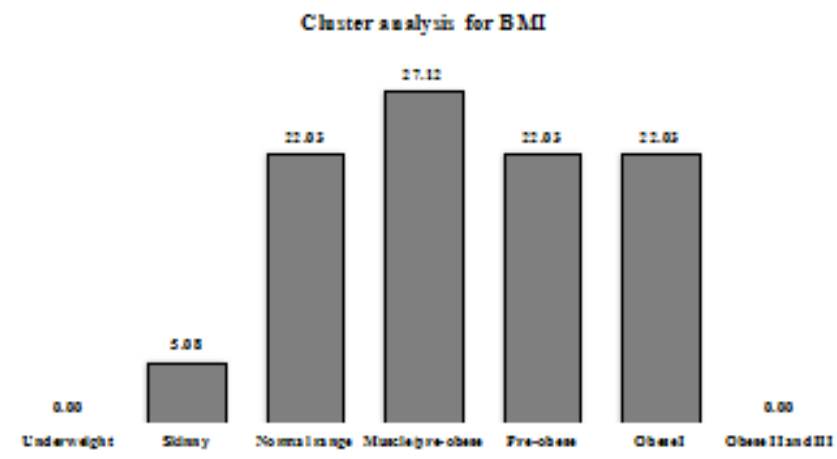

Graph 6. Prevalence of subjects in certain BMI cluster according to the WHO classification

Chuster analysis for PBF

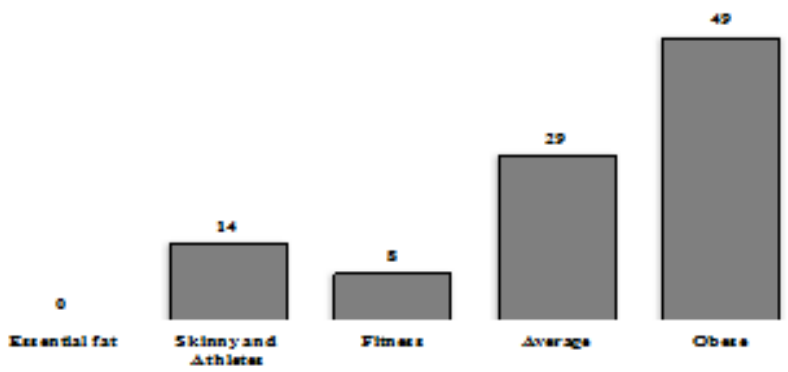

Graph 7. Prevalence of subjects in certain PBF cluster according to the ACE classification 


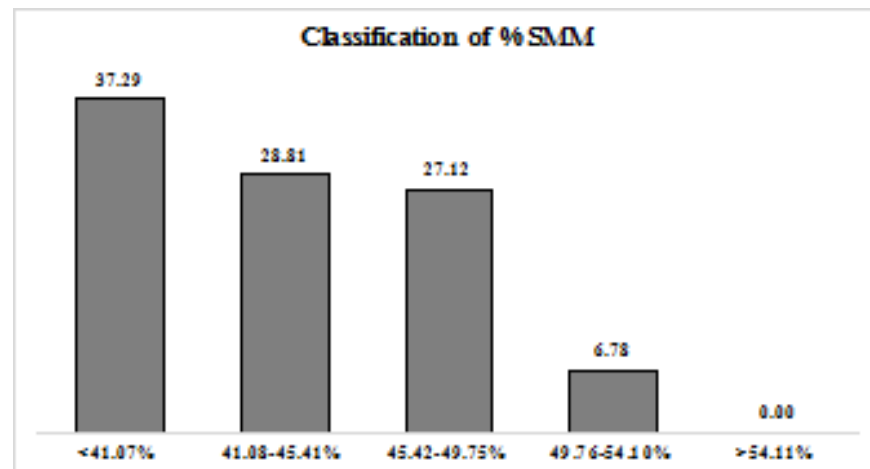

Graph 8. Classification of PSMM according to the method used in Rakić et al. 2013.

\section{Discussion}

The data collected in this study gave a unique opportunity for developing the initial model of body composition and gave the first insight into the structure of body composition of Abu Dhabi police officers. The chosen variables are the ones that explain the space of body morphology very precisely because of its connection to the nature of their job, age, gender and environmental influence. ${ }^{34,35,36,37,38}$

Based on the results of the shape and normality of data distribution shown on Graphs 1-5, it can be concluded that Skewness and Kurtosis were placed within the range of: from Skewness $=0.091$ for BW to Skewness $=-0.467$ for PSMM, as well as from Kurtosis $=0.003$ for BW to Kurt $=1.073$ for H. This proves that all variables were distributed according to the standards of normality of data distribution where the results are placed within the range of -2 to $2 .{ }^{39}$

Average body height of the sample was $173.06 \pm 6.13 \mathrm{~cm}$ with a range of 156-191 cm (Table 4). According to this result, Abu Dhabi police is $8 \mathrm{~cm}$ shorter then police from Serbia $-181.16 .4 \mathrm{~cm}$ and Finland $-181.5 \mathrm{~cm}$. Comparing with Slovenian police $-176.5 \pm 6.2 \mathrm{~cm}$, the studied sample is shorter for $3 \mathrm{~cm}$ and $6 \mathrm{~cm}$ shorter than British police.

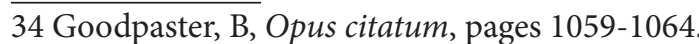

35 Stevens, J. C, Opus citatum, pages 1-7.

36 World Health Organisation, Oposum citatum

37 Despres, J., Lamarche, B, Opus citatum, pages 137-159.

38 Janssen I., Heymsfield, B., Wang, Z., Ross, R, Opus citatum, pagers 81-88.

39 Hair, J., Anderson, R., Tatham, R., Black, W; Multivariate data analysis (5th ed.)., USA:

Prentice-Hall. Inc., New Jersey, 1998. 
Average body weight of our sample was $80.10 \pm 11.5 \mathrm{~kg}$, which is about 2 $\mathrm{kg}$ less than Canadian recruiters $-82.4 \pm 12.6 \mathrm{~kg}$ and $15 \mathrm{~kg}$ less than the same group after 12 years of service $-94.6 \pm 15.9 \mathrm{~kg} .{ }^{40}$ Comparing to British police from $1987(84.4 \pm 12.4 \mathrm{~kg})$, Abu Dhabi police was lighter for $4 \mathrm{~kg}$ but also shorter for $6 \mathrm{~cm} .{ }^{41}$ Serbian police $(91.313 .5 \mathrm{~kg}$ ) was $11 \mathrm{~kg}$ heavier than Abu Dhabi police but also $10 \mathrm{~cm}$ taller. ${ }^{42}$ When we calculated the average body height and body weight for police officers from Canada, Serbia, Finland and Great Britain $(178 \mathrm{~cm}$ and $86.4 \mathrm{~kg}$ ), Abu Dhabi Police was $5 \mathrm{~cm}$ shorter and $6.9 \mathrm{~kg}$ lighter.

Graph 6 shows that $22.03 \%$ of the sample falls in the group of obese I and pre-obese while $27.12 \%$ falls in the group of muscular/pre-obese. Therefore, the prevalence of the overweighed subjects with BMI greater than $25 \mathrm{~kg} / \mathrm{m}^{2}$ was $71.18 \%$, which means that they have evident excess weight. It is clear for the pre-obese and obese class I where the excess weight comes from, but to calculate more precisely the excess weight in muscular/pre-obese group PBF criteria has to be used. $27.12 \%$ has consisted of the subjects that are overweighed because they have a higher percentage of SMM (muscular) or they have a higher percentage of body fat (pre-obese). All the subjects whose higher BMI is fat-related might be considered as pre-obese. After consolidating the results according to $\mathrm{BMI}$ and $\mathrm{PBF}, 15 \%$ of the muscular/pre-obese group was pre-obese, and $12.12 \%$ was more muscular. That means that $59.06 \%$ of the sample could be considered as overweight, $34.17 \%$ would be average, and $6.77 \%$ could be considered as underweight.

Generally, the prevalence of subjects with normal weight $(\mathrm{BMI} \leq 24.99)$ was $28.80 \%$ together with skinny and underweight. Muscular subjects from the muscular/pre-obese group (12\%) are also considered as normally-weighted persons who increase the total prevalence of the subjects with normal weight and hypothetically, we can say that the prevalence of normally-weighted participants is $39.80 \%$. On the other hand, the results show that the prevalence of pre-obese and obese subjects is $44.06 \%$. However, as explained above, $15 \%$ from the muscular/pre-obese group is also considered pre-obese, which increases the prevalence to $59.06 \%$.

In other words, practical distribution of 100 policemen would be as follows: 2 would be underweighted, 5 would be skinny, 22 would have normal weight, 12 would be muscular, 15 would be pre-obese, and 22 would be an obese class I and 22 would be obese class II and III. Obviously, 59 of them would be obese to some extent, and that means that more than every second policeman would have excess weight. Similar results were shown on the sample from Serbian

40 Boyce RW, Jones GR, Lloyd CL, Boone EL, Opus citatum, pages 1-13.

41 Spitler, D.L., Facsm, J., Hawkins, J., Dudka, L, Opus citatum, pages 154-157.

42 Dopsaj, M., Vuković, M, Opus citatum, str. 28-48. 
police. ${ }^{43}$ The prevalence in this study was $16.44 \%$ (BMI 30.00-34.99), $29.35 \%$ (BMI 27.50-29.99), 32.49\% (BMI 25.00-27.49) and 18.40\% (BMI $\leq 24.99$ ). Research on 408 police officers (300 males and 108 female) has shown obesity prevalence of $40 \%$, where the prevalence among males was $48.3 \%{ }^{44}$ Also, the research with Brazilian police showed that the prevalence was $63.9 \%{ }^{45}$

Table 5. Average BMI and PBF for different countries from different continents.

\begin{tabular}{lccc}
\hline REFERENCE & PBF & BMI & Country \\
\hline Sorensen, J.S., 2000 & - & $27.3 \pm 3.7$ & Finland \\
\hline Violanti et al., 2006 & 26.97 .1 & $28.5 \pm 5.7$ & USA \\
\hline Charls et al., 2008 & & $28.0 \pm 4.4$ & USA \\
\hline Boyce et al., 2008 & $25.31 \pm 6.1^{\mathrm{a}}$ & - & Germany \\
\hline Donadussi et al. 2009 & $20.9 \pm 5$ & $26.6 \pm 4$ & Brazil \\
\hline Zorec, B., 2009 & & $26.03 \pm 6.9$ & Slovenia \\
\hline Violanti et al., 2011 & - & $29.0 \pm 3.8^{\mathrm{a}}$ & USA \\
\hline Alasagherini et al., 2011 & $29.6 \pm 7.7$ & $29.3 \pm 4.5$ & USA \\
\hline Gu et al., 2012 & $25.8 \pm 6.2$ & $29.1 \pm 4.4$ & USA \\
\hline Dopsaj et al., 2015 & $21.02 \pm 6.43$ & $27.8 \pm 3.5$ & Serbia \\
\hline Average & $24.92 \pm 6.42$ & $27.95 \pm 4.54$ & \\
\hline
\end{tabular}

It looks that the high prevalence of obesity among the police around the world has been a regular phenomenon as shown in Table 5. Similar results for the level of obesity prevalence could probably be due to nature of work, bad eating habits, low level of physical activity outside of work as well as other personal, social and cultural factors. It could be concluded that the prevalence of obesity among police employees is very high in different countries from different continents regardless of the economic development of the country.

43 Dopsaj, M., Vuković, M, Opus citatum, str. 28-48.

44 Gu, J., Charles, L., Burchfiel, C., Fekedulegn, D, Sarkisian, K, Andrew, M., et al; Long work hours and adiposity among police officers in a US Northeast city, Journal of Occupational Environment Medicine, issue 54, volume 11/2012, pages 1374-1381.

45 Donadussi, C., Oliveira, A., Fatel, E., Dichi, J., Dichi, I; Dietary fats and measures of adiposity in military policemen, Brazilian Journal of Nutrition, issue 22, volume 6/2009, pages $847-855$. 
The existing results have shown that the prevalence is gradually raising by each year spent in service. ${ }^{46,47,48,49,50}$

Bioelectrical impedance has been very reliable and precise method for estimating fat mass in the human body. This is the most important precondition for estimating fat mass relative to body weight - percent of body fat. Table 5 shows the results for PBF in different countries and comparing to the sample of this study there is no big difference. Average PBF for different countries was $24.92 \pm 6.42 \%$ while PBF for our sample was $24.35 \pm 7.57 \%$. According to the ACE classification the sample of this study was classified as follows: there were no subjects with PBF below 5.99\%; $13.56 \%$ of the sample were classified in group with $\mathrm{PBF}=6-13.99 \% ; 8.47 \%$ of the sample were in group with $\mathrm{PBF}$ $=14-17.99 \% ; 28.81 \%$ of the sample were in group with $\mathrm{PBF}=18-24.99 \%$; and $49.15 \%$ of the sample were subjects with PBF above 25\% (Graph 7). Therefore, the conclusion is that every other participant was obese. The same as it was the case with BMI, the prevalence of obesity regarding PBF is also very high, and it could be an additional explanation of the assumption that high BMI in this study is based mainly on high PBF. It could be concluded that the sample of this study has high BMI based on high PBF, which most probably could be the result of joined effects of physical inactivity, unusual climate conditions, inadequate diet and nature of work.

The average PSMM in this study was $43.314 .49 \%$ with a range of Min = $34.79 \%$ to $\mathrm{Max}=51.69 \%$. Comparing with the results of Janssen's research based on 268 male subjects, the SMM of our sample was lower for $1 \mathrm{~kg}$ or $4 \%$. Although the sample of this study is relatively small for making general and final conclusions, the rates of SMM are similar to those that Janssen got on a bigger mixed sample (Caucasian, Afro-Americans, Asians and Hispanic) from another continent. This could mean that there are a good reliability and validity of our study. ${ }^{51}$ Regarding that, the sample of this study has been divided into 5 classes according to the method used in the previous study shown on Graph $8 .^{52}$ From the graph it can be seen that $37.29 \%$ of the sample falls in the group with insufficient percentage of skeletal muscle mass, $28.81 \%$ of the sample falls into the group with below average percentage of skeletal muscle mass, $27.12 \%$

46 Dopsaj, M., Vuković, M, Opus citatum, str. 28-48.

47 Sorensen, J. S, Opus citatum, pages 2-10.

48 Zorec, B. Anthropometric Characteristics in Police Officers, dostupno na:https://www. fvv.um.si/varstvoslovje/articles/zorec_vs_2008-4_ang.pdf (05.10.2016).

49 Da Silva, F., Hernandez, S., Goncalves, E., Arbancibia, B., Castro, T., Da Silva, R; Anthropometric indicators of obesity in Policemen: A systematic review if observational studies, International Journal of Occupational Medicine and Environmental Health, issue 27, volume 6/2014, pages 891-901.

50 Boyce RW, Jones GR, Lloyd CL, Boone EL, Opus citatum, pages 1-13.

51 Janssen, I., Heymsfield, S., Baumgartner, R., Ross, R, Opus citatum, pages 465-471.

52 Rakić, S., Marković, M., Dopsaj, M., Mlađan D., Subošić, D, Opus citatum, pages 23-33. 
of the sample has average percent of skeletal muscle mass, $6.78 \%$ of the sample has above average percentage of skeletal muscle mass, while $0 \%$ has excellent percentage of skeletal muscle mass. By simple math, we can calculate that $66.10 \%$ of the sample has below average or insufficient percentage of skeletal muscle mass which additionally explains $59.06 \%$ prevalence of obesity or high BMI due to high PBF; because lower PSMM in the body leads to increased level of BMI due to increased amount of fat mass. Lower PSMM and higher PBF tell us that the given results are most probably the result of insufficient physical activity and bad eating habits. ${ }^{53,54,55}$

The prevalence of subjects with above average and excellent percentage of skeletal muscle mass in total was $6.78 \%$. This low percentage could be partly because of the used classification method and partly because the sample size was small and with a small age range. The sample from the study whose method we used here had PSMM (Mean \pm SD $-47.59 \pm 4.34 \%)$ while our sample had PSMM 4.28\% lower. Also, the age range of the sample of the mentioned study was 19-29 years, and there was a certain number of students while on the other side, our sample consisted of only regularly working employees of Abu Dhabi police. Accordingly, it is possible that the sample from used research had higher PSMM on account of students because they are more active during the day and usually they have more free time for different physical activities. The culture of the United Arab Emirates could also be one of the factors that might have an influence on quantity and quality of physical activity and eating habits because the Emirati people start their families relatively early and often they have 3 or more children by the age of 30 . This important phenomenon should be taken into consideration in future investigations.

\section{Conclusion}

In this research the following characteristics were established as a starting point for defining body morphology of the measured employees of Abu Dhabi Police: age $-31.53 \pm 9.42$ years, $\mathrm{H}-173.08 \pm 6.13 \mathrm{~cm}, \mathrm{BW}-80.10 \pm 11.1 \mathrm{~kg}$, BMI - 26.76 $\pm 3.74 \mathrm{~kg} / \mathrm{m}^{2}, \mathrm{PBF}-24.35 \pm 7.57 \%$, SMM - 34.47 $\pm 4.78 \mathrm{~kg}$ and PSMM - $43.31 \pm 4.49 \%$. BMI, PBF, and PSMM of the sample were classified to classes so the insight of prevalence relative to those variables could be calculated. According to these results, our sample is similar to the results of a few studies conducted on the sample consisting of police officers from different countries, so it could be concluded that the police officers from Abu Dhabi police are not

53 Despres, J., Lamarche, B, Opus citatum, pages 137-159.

54 Boyce RW, Jones GR, Lloyd CL, Boone EL, Opus citatum, pages 1-13.

55 Rakić, S., Marković, M., Dopsaj, M., Mlađan D., Subošić, D, Opus citatum, pages 23-33.

[32] NBP • Žurnal za kriminalistiku i pravo 
significantly different in comparison to their colleagues around the world. The prevalence of obesity of $59.06 \%$ is quite similar to the one of those around the world. This similarity of the samples and results from around the world clearly confirms that physical inactivity, eating habits and nature of work have a huge impact on body composition of employees. Thus, we may conclude that seeking for a solution to the problem of work-related obesity is very important.

Because physical activity has very positive influence on stress relief, speeds up the metabolism and blood flow, plus it is the only natural way of muscle mass development, it is imperative to find the way to motivate police officers to work out regularly. On the other side, it is very important to find the way how to motivate them to eat properly. In both cases, the most important factor is a systematic professional solution, which would lead to consciousness towards physical activity and individual motivation. Accordingly, finding solution for these issues probably lies in the multidisciplinary approach to the problem, where knowledge from newest psychology, physical activity, and diet studies will be implemented altogether.

\section{Limitations}

There are few methodological sources of limitations that might have an impact on the results represented in this study. The participants were measured at the time when they were able to come. This meant that there was no control over any intake of food or fluid, which is not proposed by InBody 720 guide. The size of the sample was not big enough to have the results generalized towards a greater population of Abu Dhabi police. The age range of the sample was 20 years, where the oldest participant was 49 years old. Generalization of the results to larger population older than 49 years is hypothetically very small. Gender of the sample was male only. Accordingly, we were able to reach conclusions for male population only. It is also important to mention that the sample consisted only of the employees that had a certain amount of physical activity. This is due to the fact that only officers that were the members of the gym were measured. In the future, it would be necessary to expand this study with a randomized mixed sample, which would increase validity and power of generalization of the results to a wider portion of police personnel. 


\section{Acknowledgement}

This research is a part of the project Effects of applied physical activity on the locomotor, the metabolic, psychosocial and educational status of the population of the Republic of Serbia, under number III47015, which is financed by Ministry of Education and Science of the Republic of Serbia - Cycle of Projects 2011-2016.

\section{References}

1. Alasagherin MH., Clark, MK., Ramey, SL., Grueskin, EF; Body mass index misclassification of obesity among community police officers, $A A O H N$ Journal: Official Journal of the American Association of Occupational Health Nurses, issue 59, volume 11/2011, pages 469-475.

2. American Council on Exercise, Retrieved from: https://www.acefitness.org/ acefit/healthy-living-article/60/112/what-are-the-guidelines-for-percentageof-body-fat

3. Andern, C., Katzmarzyk, P., Janssen, J., Ross, R; Discrimination of health risk by combined Body Mass Index and waist circumference, Obesity Research, issue 11, volume 1/2003, pages135-142.

4. Boyce RW, Jones GR, Lloyd CL, Boone EL; A longitudinal observation of police: body composition changes over 12 years with gender and race comparisons, Journal of Exercise Physiology, issue 11/2008, pages 1-13.

5. Charles LE., Burchfel, CM., Violanti JM., Fekeduglen, D., Slaven, JE., Browne, RW; Adiposity measures and oxidative stress among police officers, Obesity, issue 16, volume 8/ 2008, pages 2489-2497.

6. Christopher I. Ardern, P. T; Discrimination of health risk by combined body mass index and waist circumference, Obesity Research, issue 11, volume1/2003, pages 135-142.

7. Da Silva, F., Hernandez, S., Goncalves, E., Arbancibia, B., Castro, T., Da Silva, R; Anthropometric indicators of obesity in Policemen: A systematic review if observational studies, International Journal of Occupational Medicine and Environmental Health, issue 27, volume 6/2014, pages 891-901.

8. Despres, J., Lamarche, B; Effects of diet and physical activity on adiposity and body fat distribution: implications for the prevention of cardiovascular disease, Nutrition Research Reviews, 6/1993, pages 137-159. 
9. Dimitrijević, R., Umičević D., Dopsaj, M; Mofološki model ženskih pripadnika komunalne policije Beograda, Glasnik antrolološkog društva srbije, 48/2013, pages 97-106.

10. Donadussi, C., Oliveira, A., Fatel, E., Dichi, J., Dichi, I; Dietary fats and measures of adiposity in military policemen, Brazilian Journal of Nutrition, issue 22, volume 6/2009, pages 847-855.

11. Dopsaj M., Nešić, G., Korpanovski, N., Sikimić, M; Antropološki profil studentkinja KPA i različito treniranih sportiskinja - multi centroidni model, Nauka, Bezbednost, Policija, vol. 14, broj 1/2009, str. 145-160.

12. Dopsaj, M., Vuković, M; Prevalenca indeksa telesne mase (BMI) kod pripadnika MUP-a Republike Srbije: Pilot istraživanje, Bezbednost, vol. 3/2015, str. 28-48.

13. Goodpaster, B; The loss of skeletal muscle strenght, mass, and quality in older adults: The health, aging and body composition study. Journal of Gerontology, issue 61A, volume 10/2006, pages 1059-1064.

14. Gu, J., Charles, L., Burchfiel, C., Fekedulegn, D, Sarkisian, K, Andrew, M., et al; Long work hours and adiposity among police officers in a US Northeast city, Journal of Occupational Environment Medicine, issue 54, volume 11/2012, pages 1374-1381

15. Hair, J., Anderson, R., Tatham, R., Black, W; Multivariate data analysis (5th ed.)., USA: Prentice-Hall. Inc., New Jersey, 1998.

16. Hughes, V; Longitudinal changes in body composition in older men and women: role of body weight change and physical activity, American Journal of Clinical Nutrition, issue 76, volume 2/2002, pages 473-481.

17. Janssen I., Heymsfield, B., Wang, Z., Ross, R; Skeletal muscle mass distribution in 468 man and women aged, Journal of Applied Physiology, issue 89 , volume $1 / 2000^{a}$, pages $81-88$.

18. Janssen, I., Heymsfield, S. R., Ross, R; Low relative skeletal muscle mass is associated with functional impairment and physical disability, Journal of the American Geriatrics Society, issue 50, volume 5/2002, pages 889-896.

19. Janssen, I., Heymsfield, S., Baumgartner, R., Ross, R; Estimation of skeletal muscle mass by bioelectrical impedance analysis. Journal of Applied Physiology, issue 89 , volume $2 / 2000^{\mathrm{b}}$, pages $465-471$.

20. Rakić, S., Marković, M., Dopsaj, M., Mlađan D., Subošić, D; Initial model of Men's muscle structure indicators defined by the method of Multichannel Bioelectrical Impedance, Facta Universitatis, Series: Physical Education and Sport, issue 11, volume 1/2013, pages 23-33. 
21. Sorensen, J. S; Physical activity, fitness and body composition of Finnish police officers: a 15-year follow-up study. Occuptional Medicine, issue 50, volume $1 / 2000$, pages $2-10$.

22. Spitler, D.L., Facsm, J., Hawkins, J., Dudka, L; Body composition and physiological characteristics of law enforcement officers. British Journal of Sports Medicine, issue 21, volume 4/1987, pages 154-157.

23. Stevens, J. C; The effect of age on the association between body-mass index and mortality, The New England Journal of Medicine, issue 338 vol 1/1998, pages 1-7.

24. Violanti JM., Fekedulegn D., Charls, LE., Hartley, TA., Burchfiel, CM; Adiposity in policing: Mental health consequences, International Journal of Mental health, issue 13, volume 4/2011, pages 257-266.

25. Violanti, JM., Burchfiels, CM., Andrew, ME., Dorn, J., Wactawski-Wende, J., et al; The Buffalo cardio-metabolic occupational police stress (BCOPS) pilot study: Methods and participant characteristics, Annals of Epidemiology, issue 16, volume 2/2006, pages 148-156.

26. Wannamethee, A., Shaper, G., Morris, R., Whincup, P; Measures of adiposity in the identification of metabolic abnormalities in elderly men, American Journal of Clinical Nutrition, issue 81, volume 5/2005, pages 1313-1321.

27. World Health Organisation. Retreived from: http://apps.who.int/bmi/index.jsp?introPage=intro_3.html (25.09.2016).

28. Zorec, B. Anthropometric Characteristics in Police Officers, dostupno na: https://www.fvv.um.si/varstvoslovje/articles/zorec_vs_2008-4_ang.pdf (05.10.2016).

\section{STRUKTURNA ANALIZA KARAKTERISTIKA TELESNOG STATUSA ZAPOSLENIH U POLICIJI ABU DABIJA}

\section{Filip Kukić}

\section{Milivoj Dopsaj}

Fakultet sporta i fizičkog vaspitanja Univerziteta u Beogradu

Sažetak: Policijski službenici imaju širok spektar zaduženja kao što su dugotrajna sedenja u kancelariji, saobraćajne i šetajuće pa- 
trole, obezbeđenje lica, objekata i manifestacija, i mnoga druga. Opšte je poznato da je telesni sastav pokazatelj trenutnog stanja organizma jer je rezultat ishrane, stresa, količine fizičke aktivnosti i drugih činilaca koji su deo ljudske svakodnevice. Praćenje morfološkog statusa je neophodno jer je telesna struktura čoveka veoma važna, a istovremeno je biološki veoma promenljiva kategorija, na koju deluju mnogobrojni, što spoljašnji što unutrašnji faktori. Cilj istraživanja bio je strukturna analiza aktuelnog stanja, a za potrebe definisanja inicijalnog modela telesnog statusa zaposlenih u policiji Abu Dabija. Merenje je realizovano u okviru sportske sekcije odseka strateškog menadžmenta i poboljšanja performansi u teretani namenjenoj uniformisanim licima zaposlenim u Ministarstvu unutrašnjih poslova Abu Dabija metodom bioelektrične impedance „In Body 720“. Uzorak ispitanika činilo je 59 policajaca muškog pola, različitog ranga i uzrasta. Osnovne karakteristike uzorka bile su: starost 31,53 \pm 9,42 godina, telesna visina $173,08 \pm 6,13 \mathrm{~cm}$ i telesna masa $80,10 \pm 11,50 \mathrm{~kg}$. Praćnene varijable bile su telesna visina (TV), telesna masa (TM), indeks telesne mase (BMI), količina masti u telu (BFM), procenat masti $\mathrm{u}$ telu (PBF), količina mišićne mase (SMM) i procenat mišića u telu (PSMM). Rezultati su statistički obrađeni primenom deskriptivne statistike i klasterske analize i dobijene su sledeće vrednosti karakteristika telesne strukture kao osnove za definisanje morfologije tela kod ispitivanih pripadnika policije Abu Dabija: BMI $26,76 \pm 3,74 \mathrm{~kg} / \mathrm{m}^{2}, \mathrm{PBF}-24,35 \pm 7,57 \%, \mathrm{SMM}-34,47 \pm 4,78 \mathrm{~kg}$ i PSMM - 43,31 $\pm 4,49 \%$. U odnosu na BMI, PBF i PSMM uzorak je raspoređen $\mathrm{u}$ klastere kako bi se stekao uvid u prevalencu $\mathrm{u}$ odnosu na uhranjenost i procenat masnog i mišićnog tkiva. Dobijeni rezultati su pokazali da je prevalenca prekomerno uhranjenih prema klasterima WHO iznosila 59,06\%, prevalenca gojaznosti prema ACE $49,15 \%$, dok je čak $66,10 \%$ uzorka imao ispod prosečan ili nedovoljan PSMM. 